Article

\title{
Baptism in the Holy Spirit-and-Fire: Luke's Implicitly Pneumatological Theory of Atonement
}

\author{
Frank D. Macchia \\ Department of Religion, Vanguard University of Southern California, Costa Mesa, CA 92626, USA; \\ fmacchia@vanguard.edu
}

Received: 21 December 2017; Accepted: 12 February 2018; Published: 24 February 2018

\begin{abstract}
Historically, theologies of atonement have neglected the Holy Spirit. Luke provides us with an important canonical voice for addressing this neglect. Luke locates Christ's salvific work within his mission to baptize all flesh in the Holy Spirit and fire. He is to occasion a "river" of the Spirit through which all must pass, either unto destruction or salvation. Christ must himself pass through this river to be the Spirit Baptizer. He must pass through the baptism of fire on the cross so as to bring others into the blessings of the Spirit.
\end{abstract}

Keywords: Luke; atonement; pneumatology; Spirit baptism

Theologies of atonement have not traditionally paid much attention to the Holy Spirit. It may be said that Anselm neglected a positive role for the Father in his famous Cur Deus Homo; and the same can surely be said of the Spirit. ${ }^{1}$ Even the attention paid in recent decades to the cross as a Trinitarian act tended to concentrate on the relationship between the Father and the Son. ${ }^{2}$ Luke is a voice from the canon that can help theologians address this lack. Luke is unique among the evangelists in describing the larger significance of Christ's death as a passage to Pentecost or the outpouring of the Spirit. I affirm here James Dunn's conclusion that, for Luke, "the climax and proposed end of Jesus' ministry is not the cross and the resurrection, but the ascension and Pentecost" (Dunn 1970, p. 44). Luke stands out in the prominence that he gives to John the Baptist's announcement that the Messiah will baptize in the Holy Spirit and fire. Luke makes this messianic baptism the key to understanding Christ's entire mission, for in Luke's Gospel, Jesus is himself baptized in the Spirit and fire in order to baptize others in the Spirit. Above all else, Jesus is for Luke the Spirit Baptizer. This focus on Jesus as the Spirit Baptizer means that Luke invites us to view the salvific work of Christ as occurring in the presence of the Holy Spirit, the river through which all must pass, either unto purgation and renewal or judgment and destruction. Jesus must himself pass through that river; he must be baptized in the Spirit and fire on the way to baptizing others. This passage through the Spirit helps us to see the cross in Luke's Gospel in the context of a new exodus motif, but one that is pneumatological through and through, since the goal of freedom is the life of the Spirit.

\section{The Baptist's Announcement:}

Our point of departure is thus this announcement by John the Baptist:

I baptize you with water. But one who is more powerful than I will come, the straps of whose sandals I am not worthy to untie. He will baptize you with the Holy Spirit and fire.

See my discussion of Anselm in (Macchia 2010, pp. 155-64).

(Macchia 2010, pp. 131-85); A good introduction to this trend is found in (Hunt 1997). For a major Protestant voice, see (Moltmann 1993). Largely in response to Moltmann, D. Lyle Dabney has sought to grant the Spirit a more prominent role in the atonement than has traditionally been the case. See his, (Dabney 2000). 
His winnowing fork is in his hand to clear his threshing floor and to gather the wheat into his barn, but he will burn up the chaff with unquenchable fire. (3:16-17)

John's baptism was a prophetic drama of hope. This drama is connected mainly to the Jordan's historic significance as important to the journey of the original exodus community. If not for this drama, the Jordan River would have been an unlikely place for John's water rite to take shape and to flourish. It was not conducive for mass baptisms. The water there was difficult to access in the winter months, and its relatively shallow depth raised questions about its adequacy to meet common standards of purity. It seems that John's baptism was a drama of a new Israel leaving its sins behind and re-emerging from the Jordan in hopes of renewal as a people (Brown 1997). This baptismal drama was thus symbolic of a people welcoming the coming era of the Spirit, even to the degree that John the Baptist would make it part of his proclamation of the kingdom of God (Luke 3:3).

John's announcement that the Messiah will occasion a "river" of the Spirit and fire through which Israel must pass unto renewal or destruction is key to his significance as the one who foretells of the coming renewal. John may have taken from Qumran the idea that God "will make known to them his Holy Spirit through his Messiah." ${ }^{3}$ For John the Baptist, the Messiah will "make known" the Holy Spirit by imparting the Spirit to all flesh. With Joel 2:28-32 in the background (Acts 2:17-21), this event of Spirit impartation is of apocalyptic significance for Luke. There are indeed signs given at the Jordan that indicate an apocalyptic event: the heavens open, and God's voice is heard making an announcement of Jesus as the beloved Son (Nolland 1989, p. 162). And the Spirit appears in the form of a dove, reminiscent of the Spirit's brooding on the waters of creation and the sign of new creation in the story of Noah (Hagner 1993, p. 58). Kilian McDonnell is right. In a very real sense, for Luke, "eschatology begins at the Jordan" (McDonnell 1996, p. 148).

John's water rite anticipates the new eschatological community purged and renewed by the Spirit but does not inaugurate it. He baptized in water unto repentance and hope. The passage through the water of the Jordan by those baptized by John dramatized a journey of hope that reached for a renewed Israel. But John would not be the one to usher in this communal and eschatological renewal. Only the era of the Spirit can do this, and only the Messiah can bring the Spirit and transform the covenant community in this way. Only he represents in his person this renewed community in his own journey through the Spirit-and-fire. This is the very Spirit that mediated Christ's coming into the world (1:35) and into which Christ himself is "baptized" so that he could impart this Spirit to others. John's baptism is thus only preparatory. He lacks eschatological transcendence. Only the Messiah will occasion a river of the Spirit into which he descends so that he could baptize others unto purgation and renewal.

The messianic Spirit baptism, however, will not only occasion purgation and renewal: it will occasion a fire baptism of devastating judgment. John the Baptist notes that the "winnowing fork is in his hand to clear his threshing floor and to gather the wheat into his barn, but he will burn up the chaff with unquenchable fire" (3:17). John the Baptist brings together the images of wind and fire; the wind separates the repentant from the unrepentant and sweeps the unrepentant into the river of fire. For the unrepentant, the river of the Sprit becomes a river of fiery judgment (the metaphor in the text changes at this point). The devastating effects of this flood of judgment in John's announcement reminds one of texts like Isaiah 30:28: "His breath is like a rushing torrent, rising up to the neck. He shakes the nations in the sieve of destruction; he places in the jaws of the peoples a bit that leads them astray." Judgment is sometimes described as a mighty flood. Jonah sinks beneath the waves of death and alienation from God: "I have been banished from your sight" (Jonah 2:4). Jonah's experience is especially relevant, since Luke shares with Matthew a connection between Christ's messianic mission and the experience of Jonah, who is raised up from oblivion to proclaim God's grace to the Ninevites (Jonah 2:1-6; Luke 11:29-32). As Dunn writes, "It was the fiery $\pi v \varepsilon v \tilde{\mu} \alpha$ in which all must be immersed, 
as it were, and which like a smelting furnace would burn up all impurity. For the unrepentant, it would mean total destruction. For the repentant, it would mean a refining ... which would result in salvation" (Dunn 1970, pp. 13-14). Such would be the gateway to the new covenant community for Luke. Though "Spirit" seems to accent the renewal and "fire" the judgment, Dunn helpfully views the messianic baptizing "in Spirit-and-fire" as a single baptism with two very different effects. It is the "Spirit-and-fire" baptism of which John speaks that results in either covenant renewal or alienation and destruction.

The effects of this baptism in "Spirit-and-fire" will proceed beyond the boundaries of Israel for Luke. Tellingly, Luke traces Jesus' lineage to "Adam the son of God" (3:38). Just prior to this naming of Adam as the son of God, Christ as the eschatological Adam is hailed the Son of God by his heavenly Father at the waters of the Jordan to fulfill the mission to Adam and Eve's seed (Ibid., p. 31). As Luke writes, "The Holy Spirit descended on him in bodily form like a dove. And a voice came from heaven: 'You are my Son, whom I love; with you I am well pleased'"' (3:22). Jesus is already named the holy Son of God in Mary's womb according to Luke, for the Spirit overshadows her for this purpose (1:35). Jesus is conceived by the Holy Spirit, while John the Baptist is only filled with the Spirit in his mother's womb (1:15). Only Jesus is to be the mediator of the Spirit to all flesh; only his conception has this kind of eschatological significance. And only of Jesus is it said that he will take the throne of David and reign over Jacob's descendants forever (1:32-33). Clearly, only Jesus is to usher in the era of the Spirit and fire. Only he is to be the Lord of the Spirit and of the future era of salvation (cf., Acts 2:36).

As Jesus came forth from Mary's womb through the mediation of the Spirit as the consecrated Son of God, so also Jesus comes forth from the Jordan anointed by the Spirit for his mission as the Spirit Baptizer. To baptize in the Spirit, however, the beloved Son must endure the "Spirit-and-fire" baptism in its most devastating form. His victory at the Jordan is followed by his trial in the desert. This trial is only the beginning of the suffering that the Messiah must endure. He endures the trial that was not only analogous to the one endured by Israel in the desert but also the one faced by Adam and Eve in the Garden. Indeed, Jesus faces a formidably dark tempter in the desert upon the launching of his mission at the Jordan. Adam was made a living soul by receiving the breath of God, but after failing in the Garden, he was destined to return to dust (Gen. 2:7; 3:19). Jesus bears the Spirit to rewrite Adam's story so as to conclude it with a very different fate. Christ will rise up from Adam's dust to impart the Spirit of life to all of Adam's seed. His inaugural address promises that he bears the Spirit to liberate the oppressed and proclaim the year of the Lord's favor (4:18). But that proclamation will be tested even further, before it comes to fulfillment. He will be swallowed up in death like Jonah who was cast beneath the waves in alienation from God. The baptism in "Spirit-and-fire" is key to Luke's theology of atonement.

\section{Jesus' Baptism in Fire:}

Luke's understanding of the atonement as a baptism in fire emerges from an examination of Luke 12:49-53. This text reads as follows:

"I have come to bring fire on the earth, and how I wish it were already kindled! But I have a baptism to undergo, and what constraint I am under until it is completed! Do you think I came to bring peace on earth? No, I tell you, but division. From now on there will be five in one family divided against each other, three against two and two against three. They will be divided, father against son and son against father, mother against daughter and daughter against mother, mother-in-law against daughter-in-law and daughter-in-law against mother-in-law."

The Messiah is indeed to kindle a fire upon the earth! James and John called for this fire in Luke 9:54, but Jesus rebuked them (v.55). The time for the fire baptism was not yet. Christ must first endure this fire himself. Christ himself wished that the fire were already kindled, and the kingdom of God already fulfilled. But his own baptism in fire must come first. Nothing is possible without this. Since 
his death will occur due to the devastating effects of human rejection, betrayal, and injustice, it has as its interpretive context messianic woes that involve the divisions that will arise within households due to Christ's ministry. Such divisions are striking given the angelic announcement on the occasion of Christ's birth described for us in Luke 2:14: "Glory to God in the highest heaven, and on earth peace to those on whom his favor rests." Yet, there is also an indication in Luke 2:34 of a darker side to the messianic mission. Simeon the prophet says to Mary the mother of Jesus, "This child is destined to cause the falling and rising of many in Israel, and to be a sign that will be spoken against." The peace of the baptism in Spirit-and-fire is to be experienced in the renewed and just community for Luke. But their Spirit-empowered witness will occasion many divisions and trials to endure. Such trials will only make the community stronger and more effective. The book of Acts bears abundant witness to this Lucan conviction. However, the human rejection of grace has more dire consequences than all of this for Luke, for it ultimately put Jesus Christ, the favored and beloved Son of the Father, on the cross.

The link between Jesus and Jonah is important for understanding Jesus's experience of sinking beneath the flood of judgment at the cross. Matthew explicitly ties Christ's three days in the heart of the earth to Jonah's banishment from God three days under the waves in the belly of the fish (Matthew 12:40). Though Luke's account is not so elaborate, one can arguably make the case that Jesus' sign value in relation to Jonah's mentioned in Luke 11:29-30 implies that Jesus' resurrection or deliverance is from a plight similar to Jonah's (cf., Matthew 12:39-40). The Jonah-Jesus connection implies that Jesus' baptism in fire will be more severe than the oppression endured by Israel under Pharaoh, for Jesus faces an even darker adversary (as he did in the desert). When he sinks into the pit of alienation on the cross, his deliverance will represent a sign of grace not only for Israel as a new exodus community but also for all of humankind in relation to their condemnation and death. One greater than Jonah has arrived.

Jesus' death is described as the ultimate injustice (Acts 8:32-33), and yet, this injustice has opened the way to the Spirit and to the rise of the community that bears witness to liberation and justice. The injustice involved in the human rejection of grace is overcome at the cross as Jesus offered himself as the bearer of the Spirit to the Father's just cause in world on our behalf. He thus opens the path for those who repent to the merciful justice of community in the Spirit. The implication here is that Christ bears the verdict that his crucifiers deserve on the cross so as to open the door for them to the community of the Spirit based on him. The rejected one becomes the foundation of hope for those who rejected him: "The stone you builders rejected ... has become the cornerstone" (4:11). Christ's death could even be described as a passage to new life that is "purchased" by Christ's self-sacrifice (20:28). If those who rejected such grace repent, they will receive the Holy Spirit (2:38). Those about to be baptized are implored to seek salvation from this corrupt generation (2:40). Water baptism symbolizes passing with Christ through the river of the Spirit, which turns out to be a purgative rather than a destructive force because of him.

Christ's fire baptism is unavoidable, for it is only by passing through the fire that the Son, the last Adam, can baptize all flesh in the Spirit. As Joseph Fitzmeyer notes, Christ's fire baptism "is not one that he merely administers to others but that he must undergo; he who baptizes with fire must himself face the testing and krisis that the figure connotes" (Fitzmeyer 1970, p. 995) On the cross, Christ passes through the worst of the human rejection of grace to be sure, but also, the divine judgment that accompanies it. As the Baptizer in Spirit-and-fire, Christ stands at the turning point of history, but not simply as the Judge over others but also and principally as the one who sinks beneath the overwhelming flood of calamity himself for the sake of others, the worst of which is death within the dark plight of human rejection and alienation. Jesus bears vicariously the baptism in his death for the sake of humanity so that he could, as the one who has entered the new age of the Spirit, baptize others in the Spirit. ${ }^{4}$ 


\section{Luke's Pneumatological Theory of Atonement:}

Does Luke have an atonement theory? He excludes a ransom text such as one finds in Mark 10:45 or Matthew 20:28, and, in his account of the Last Supper, Luke lacks the phrase "poured out for many for the forgiveness of sins" (Matthew 26:28; Mark 14:24) (Gorman 2014, p. 37). At the very least, Luke is a resource for a pneumatological theory of atonement today. Toward this end, noteworthy is Michael Gorman's point that Luke refers to the Last Supper as involving a "new covenant" through Christ's blood poured out for humanity (22:20). One may add that the community that passed through the Jordan in the hope of becoming a people renewed by the Spirit will become this by the new covenant of Christ's spilled blood and, by implication, broken body. It is this self-sacrifice that leads to Jesus as the one who imparts the Spirit. His baptism in the Spirit and fire leads to his baptism of others in the Spirit: "For John baptized with water, but in a few days you will be baptized with the Holy Spirit" (Acts 1:5). Notice that Jesus does not add the "fire" of judgment to this quote from John. Could the reason be that Christ has endured this for the others so that they could escape it? It would seem so. He drank the bitter cup for them so that they could drink of the Spirit from him. He overcomes sin and death on his way to the fullness of his own vindication by the Spirit so as to open a path for others to partake of this vindication as well.

Luke's Last Supper account grants attention to the coming kingdom and to the justice to which the renewed community will bear witness: "the greatest among you should be like the youngest, and the one who rules like the one who serves" (22:26). The fact that this occurs at the Last Supper for Luke is significant. The renewed community will pass with Christ through the fire in order to receive the Spirit of renewal and hope. Their sticking with him through the fire will be rewarded: "You are those who have stood by me in my trials. And I confer on you a kingdom, just as my Father conferred one on me" (22:28-29). The satan that Christ overcame from the desert to the cross has sought to sift the disciples as wheat, but Christ has prayed for them and kept them safe (22:31-32). The destruction of the fire baptism is devastating without the passage that Christ provides through it. He walked them through the fire so that they could from him receive the Spirit and in him be the purged and renewed community that bears witness to him in the world.

Luke's understanding of atonement is essentially a new exodus, ${ }^{5}$ except the context is more potentially nefarious as well as rewarding, depending on how people respond, for the context is a passing through the Spirit-and-fire. If one passes with Christ as the man of the Spirit and Son of the Father, one passes unharmed through the fire of condemnation and destruction to receive the Spirit of renewal. This passing becomes purgative rather than destructive, for the Spirit purifies hearts by faith (Acts 15:9). By the Spirit, the Son overcomes his trial, and by the Spirit, he will bring his community through the fire to the blessings of the Spirit. He will gather his community around him as the crucified and exalted Lord. As the last Adam, Christ fulfills Israel's mission to glorify God before all flesh. Christ not only gathers them unto him by the Spirit, he fills them to overflowing so that they could withstand trials and bear witness to God's just peace for the world (1:8). The community of the Spirit will be a reconciled and reconciling community (2:17-18). They will thus bear witness to Christ not only in words but in their shared life together. They eat the bread and drink the cup of salvation because Christ drank the bitter cup of alienation from God. They speak in tongues symbolized by flaming symbols of God's holy presence because Christ bore the fire of human rejection. The baptism in water that they observe symbolizes a passage from the fire of destruction to the Spirit of renewal (chp. 2). They make this passage only by Christ, who won passage for them.

For Luke, Christ's death and resurrection culminate at Pentecost, where Christ fulfills his baptism in fire and Spirit by baptizing others in the Spirit. He is for Luke principally the Spirit baptizer, and that

5 I agree in part here with (Garrett 1990, pp. 656-80). I am also grateful to Garrett for suggesting in response to a rough draft of this paper that I highlight the new exodus motif. I also wish to thank Paul Borgman for his encouragement in this area as well. 
identity determines his mission from Mary's womb to the throne of God. As the Messiah who bore the Spirit, he becomes the Lord who imparts the Spirit (Acts 2:32-36). His death and resurrection make way for the Spirit, make way for the new covenant, the new community. From his death to his impartation of the Spirit, Christ creates a new covenant community and a new covenant loyalty. As Michael Gorman notes, for Luke, "Jesus' death, is part of a whole divine event of deliverance (suffering, death, resurrection, ascension/exaltation)" (Gorman 2014, p. 42). It also makes way for the impartation of the Spirit and for the formation of a reconciled and reconciling community filled with the Spirit of God.

There are numerous questions that one could raise about the role of the Spirit in the atonement. Within the parameters of Luke's Gospel (in the light of Acts), one may affirm that Christ's mission is to heal the alienation of flesh from Spirit. As the faithful Son and bearer of the Spirit, Christ accomplishes this reconciliation by passing through the judgmental fire on our behalf without being consumed by it. The Spirit remains with him as the means by which he is vindicated as Messiah and Lord (Acts 2:36). The result is that Christ overcomes the judgment that keeps flesh from the sanctifying work of the Spirit. He overcomes this fire in order to open a path to the Spirit for all flesh. Christ's exaltation as Lord is his ultimate victory and his first act of Lordship is the pouring forth of the Spirit upon all flesh (Acts 2:32-36). He overcomes the reign of sin and death so as to impart life. The Messiah who bears the Spirit becomes the Lord who imparts the Spirit (2:36). Christ's atonement has its victory in this wholeness of flesh and Spirit, which leads to the renewed community that witnesses to Christ in the world through the power of the Spirit and that gives all glory to the heavenly Father.

Conflicts of Interest: The author declares no conflict of interest.

\section{References}

Brown, Colin. 1997. What Was John the Baptist Doing? Bulletin for Biblical Research 7: 37-50.

Dabney, D. Lyle. 2000. Pneumatologia Crucis: Reclaiming Theologia Crucis for a Theology of the Spirit Today. Scottish Journal of Theology 53: 511-24. [CrossRef]

Dunn, James D. G. 1970. The Baptism in the Holy Sprit. Studies in Biblical Theology 15. London: SCM Press.

Fitzmeyer, Joseph. 1970. The Gospel according to Luke I-IX, The Anchor Bible. New York: Doubleday, vol. 28.

Garrett, Susan. 1990. Exodus from Bondage: Luke 9:31 and Acts 12:1-24. Catholic Biblical Quarterly 52: 656-80.

Gorman, Michael. 2014. The Death of the Messiah and the Birth of the New Covenant: A (Not So) New Model of the Atonement. Eugene: Cascade Books.

Hagner, Donald. 1993. Matthew 1-13. Word Biblical Commentary 33A. Dallas: Word.

Hunt, Anne. 1997. The Trinity and the Paschal Mystery: A Development in Recent Catholic Theology. Collegeville: Michael Glazier.

Macchia, Frank D. 2010. Justified in the Spirit: Creation, Redemption, and the Triune God. Grand Rapids: Eerdmans. Macchia, Frank D. Forthcoming. Jesus the Spirit Baptizer: Christology in Light of Pentecost. Grand Rapids: Eerdmans. McDonnell, Kilian. 1996. The Baptism of Jesus in the Jordan: The Trinitarian and Cosmic Order of Salvation. Collegeville: Liturgical Press.

Moltmann, Jürgen. 1993. The Trinity and the Kingdom. Minneapolis: Fortress Press.

Nolland, John. 1989. Luke 1-9:20. Word Biblical Commentary 35A. Dallas: Word.

(c) 2018 by the author. Licensee MDPI, Basel, Switzerland. This article is an open access article distributed under the terms and conditions of the Creative Commons Attribution (CC BY) license (http:/ / creativecommons.org/licenses/by/4.0/). 